\title{
EFFECT OF SERVICE QUALITY, RELIGIOSITY, RELATIONSHIP CLOSENESS, AND CUSTOMER TRUST ON CUSTOMER SATISFACTION AND LOYALTY AT BANK JATIM SYARIAH
}

\author{
Sapoetra Dymas Bagoes*, Basuki Rachmat \\ STIE Perbanas Surabaya, Indonesia \\ *E-mail: dymas.2509@gmail.com \\ ORCID 0000-0002-1369-3382
}

\begin{abstract}
This research aims to examine the effect of service quality, religiosity, relationship closeness, and customer trust on customer satisfaction and loyalty at Bank Jatim Syariah. Based on the literature review, the research hypothesis states that service quality and customer trust have a positive and significant effect on customer satisfaction. In addition, service quality, relationship closeness, customer satisfaction and religiosity have a positive and significant effect on customer loyalty. This research uses a questionnaire distributed to respondents/ active customers of Bank Jatim Syariah. The hypothesis testing was carried out using Structural Equation Model (SEM) analysis technique. The research findings showed that service quality and customer trust have a positive and significant effect on customer satisfaction, customer satisfaction and relationship closeness have a positive effect on customer loyalty, and service quality and religiosity have a positive and not significant effect on customer loyalty. In particular, this research shows that the religiosity factor that has been an added value for sharia banks to retain customers is no longer relevant. Based on the research findings, it is recommended that Bank Jatim Syariah evaluate the tangible, product, and service factors and implement sustainable service standards so that customer satisfaction and loyalty are maintained.
\end{abstract}

\section{KEY WORDS}

Service quality, religiosity, customer, loyalty.

Currently, sharia banking is increasingly and widely accepted in the world, including in Indonesia. The demonstration that took place in Jakarta on November 4, 2016 and the peaceful action on December 2, 2016 made people aware and wanted to transfer their funds from conventional banks to sharia banks.

This opportunity must be immediately optimized by sharia banking. Sharia banks must immediately improve the service quality to be in line with conventional banks. Access to information technology such as ATM, Mobile Banking and Internet Banking is the focus for developing service quality.

There are 5 dimensions of service quality which consist of: tangible, empathy, reliability, responsiveness and assurance (Tjiptono, 2012: 174-175; Putri \& Widodo, 2016: 3). Tangible is seen from the physical elements of the company, empathy is seen from the convenience of customers to access/ contact the company, reliability is seen from the company's ability to provide services in accordance with the promises accurately and reliably, responsiveness is seen from a company policy to help and provide fast and right services to customers, and assurance is seen from the credibility, competence and politeness of the company.

The religiosity factor also causes customers to prefer sharia banks compared to conventional banks even though the products and services of sharia banks are still limited. Therefore, product and service development innovations must also remain an important focus for sharia banks in order to compete with conventional banks.

On the other hand, the ongoing effort made by Bank Jatim Syariah to establish relationship closeness with its customers is by consistently holding open table agenda on Car Free Day (CFD) event every Sunday in Bungkul Park, Surabaya. Thus, customers who 
have not had time to transact at Bank Jatim Syariah on working hours and days can conduct banking transactions conveniently and take their families to exercise on Sunday at the same time. In addition, Bank Jatim Syariah employees will also get to know customers more closely in terms of their needs and activities.

The data in Table 1 explains the performance achievements of Bank Jatim Syariah for the 2012 - 2016 period, in which the total number of Bank Jatim Syariah customer accounts at the end of December 2016 reached more than 57,000 accounts. It increases $67 \%$ compared to December 2015 which reached approximately 34,000 accounts. The same thing happened to the total number of Third-Party Funds (TPF) which reached more than 285 billion rupiahs; it increases 32\% compared to December 2015 which reached 216 billion rupiah. It proves that customer trust in Bank Jatim Syariah is increasing. Bank Jatim Syariah guarantees to customers that Bank Jatim Syariah is able to manage funds that have been optimally mandated in accordance with sharia principles.

Table 1 - Development of Number of Accounts (NoA) and Third-Party Funds (TPF) at Bank Jatim Syariah in the 2012-2016 Period

\begin{tabular}{|c|c|c|c|c|}
\hline Year & NoA & NoA (\%) & TPF & TPF (\%) \\
\hline 2012 & 13,751 & $0 \%$ & $92,071,122,961$ & $0 \%$ \\
\hline 2013 & 18,431 & $34 \%$ & $120,531,724,640$ & $31 \%$ \\
\hline 2014 & 25,857 & $40 \%$ & $183,888,075,622$ & $53 \%$ \\
\hline 2015 & 34,186 & $32 \%$ & $216,122,740,300$ & $18 \%$ \\
\hline 2016 & 57,012 & $67 \%$ & $285,531,710,880$ & $32 \%$ \\
\hline
\end{tabular}

Source: Secondary Data.

Reports on sharia banking statistics issued by Bank Indonesia (BI) in the period 2012 to 2014 and reports on sharia banking statistics issued by the Financial Services Authority (OJK) in the period of 2015 to 2016 presented in Table 2 show that the number of branch offices of Bank Jatim Sharia at the end of 2016 reached 7 branch offices, which increased by $40 \%$ from 2015 which only reached 5 branch offices.

It proves that Bank Jatim Syariah wants to increase customer satisfaction by answering customer complaints about the difficulty of transactions at Bank Jatim Syariah by adding branch offices and sub-branch offices every year.

Table 2 - Report on the Development of Office Network of Bank Jatim Syariah

\begin{tabular}{|c|c|c|c|c|}
\hline Year & $\begin{array}{c}\text { Number of } \\
\text { Branch Office }\end{array}$ & $\begin{array}{c}\text { Increase in Number of } \\
\text { Branch Office (\%) }\end{array}$ & $\begin{array}{c}\text { Number of Sub- } \\
\text { Branch Office }\end{array}$ & $\begin{array}{c}\text { Increase in Number of Sub- } \\
\text { Branch Office (\%) }\end{array}$ \\
\hline 2012 & 1 & $0 \%$ & 3 & $0 \%$ \\
\hline 2013 & 1 & $0 \%$ & 3 & $0 \%$ \\
\hline 2014 & 3 & $200 \%$ & 5 & $67 \%$ \\
\hline 2015 & 5 & $67 \%$ & 7 & $40 \%$ \\
\hline 2016 & 7 & $40 \%$ & 8 & $14 \%$ \\
\hline
\end{tabular}

Source: Statistics on sharia banking issued by OJK in 2015-2016 and BI in 2012-2014.

Another factor that affects the growth of the office network of Bank Jatim Syariah is customer loyalty. If there are many customers who are loyal to Bank Jatim Syariah, it will have an impact on increasing Third-Party Funds (TPF) and directly affect the growth of TPF and office network of Bank Jatim Syariah. Customer loyalty is a major factor and should be pursued by Bank Jatim Syariah if it wants to seize great opportunities. Considering the importance of customer loyalty, Bank Jatim Syariah needs to make strategic efforts. Satisfied customers will tell 3 to 5 people about the product or service they receive. However, on the other hand, dissatisfied customers will tell 10 to 12 people about their dissatisfaction (Janet, 2009; Dewi et al, 2014: 261).

Bank Jatim Syariah, which is a Sharia Business Unit of PT Bank Pembangunan Daerah Jawa Timur Tbk, was established based on Bank Indonesia Letter number 9/75/DS/Sb dated April 4, 2007 concerning: Approval of the Principle of Establishing a Sharia 
Business Unit (UUS), Opening of Sharia Branch Offices, and Members of the Sharia Supervisory Board and Bank Indonesia Letter number 9/148/DPIP/Prz/Sb dated July 24, 2007 concerning: Permit for Opening of Sharia Branch Offices. Bank Jatim Syariah was inaugurated on Tuesday 21 August 2007 which coincided with 8 Sya'ban $1428 \mathrm{H}$.

In its 10 years of establishment, Bank Jatim Syariah has perfomed a lot of development and innovation to provide convenience to the public in transactions through network expansion which includes office networks, sharia services, and Electronic Channels in the form of ATM, SMS Banking, Mobile Banking, and Internet Banking.

This research focuses on what factors affect service quality, religiosity, relationship closeness and customer trust on customer satisfaction and loyalty and test and analyze these factors in relation to customer satisfaction and loyalty.

\section{LITERATURE REVIEW}

Service can be defined as any form of activity given by one or more parties to another party which aims to give satisfaction to the second party for the goods and services that have been given. Service means two elements or groups of people who each need each other and have relevance. Therefore, the roles and functions inherent in each of these elements are different.

Service quality as a result of perceptions and comparisons between customer expectations and actual service performance has 2 main factors that affect service quality; i.e. the expected experience and the services received (Pujawan, 2010: 97; Moha \& Loindong, 2016: 576).

Service quality is a beginning of customer satisfaction and also results from customer satisfaction. Service quality and customer satisfaction affect stronger visit intensity so that the improvement of service quality must be customer-oriented (Irawan, 2008: 64; Koestanto, 2014: 4).

There are five main dimensions of service quality, among others: 1) Reliability is the ability to provide services that have been promised immediately, accurately, and satisfactorily, 2) Responsiveness is the desire of employees to help consumers and provide responsive services, 3) Assurance is a guarantee that includes knowledge, competence, politeness, trustworthy characteristic of the employees, and freedom from danger, risk, or hesitation, 4) Empathy includes ease in establishing relationships, good communication, personal attention, and understanding of customer individual needs, and 5) Tangible includes physical facilities, equipment, employees, and means of communication (Tjiptono, 2009: 269; Panjaitan \& Yuliati, 2016: 270).

Service is any action or activity that can be offered by one party to another. Basically, it is intangible and does not result in any ownership. Thus, services can be utilized by service companies to create customer satisfaction. However, companies also may not exclude dissatisfied customers. Therefore, companies must know and understand what their customers need and want (Kotler, 2007: 23; Bari, 2014: 2).

Religiosity is a person's attitude towards religion in general; not just one aspect of religion. More specifically, religiosity is the intensity of a person's way to become a religious person.

Spirituality is a broader concept, which represents transcendent beliefs and values that may or may not be related to religious organizations. Religiosity on the other hand refers to rituals and beliefs that may be shown in the context of religious institutions. Spirituality can be expressed in the context of religion; yet, one's religiosity is not only caused by spirituality (Hodge et al, 2010: 3; Ghufron, 2010: 358).

Religiosity is behavior based on conscience and attachment to God which is manifested in the form of quantity and quality of worship and norms that govern relationships with God, relationships with human, and relationships with environments which is internalized in humans (Rahman, 2009; Umasugi, 2013).

Based on the above understanding, it is concluded that religiosity is a conscience and attachment to God that is manifested in various aspects of life in the form of quantity and 
quality of worship and norms that govern relationships with God, relationships with fellow humans, and relationships with environments which is internalized in humans.

The relationship closeness between employees and customers can be performed by building friendliness, credibility, employee image, and satisfaction that is felt while dealing with employees. Friendliness is important in the effort to build closeness with bank customers, and is one form of personalization that will make customers feel familiar, happy and friendly. In addition to friendliness, the credibility of employees is also an important factor for building closeness with customers (Hansen, 2003; Hariyanto, 2014: 233).

The possibility that causes customers to have more potential is to disclose information which is a type of closeness (Hansen, 2003; Halim \& Suryani, 2013: 84). It is similar to someone who will share information with his/her business partners but not by selling. The closeness of employees and customers is reflected in the customer's openness. If customers feel close to the bank, they will ask a lot about the products offered and the services they want. This condition will make it easier for banks to offer a variety of products and services.

Thus, this will be an opportunity to offer products. The closeness of employees and customers can be a competitive advantage with other banks. Banks that have managed to build loyalty with customers are usually due to the ability of banks to establish closeness with customers.

According to Barnes (in Halim \& Suryani, 2013: 84), when customers become closer to a company and its employees, there is a positive effect in the interaction between the customer and the company.

Relationship dimensions are as follows.1) Trust is something that is believed to be true. Trust will occur if one party has confidence in the reliability and integrity of the relationship partner. 2) Closeness. Relationship closeness is characterized by sincere feelings towards others. Customers make connections with a company because they like the company, like the products they offer or the people who work there; therefore, customers feel a certain closeness to them or have the same values and goals. 3) Reciprocal relationships. Relationships, that are important to both parties that will be continued by both, must provide mutual benefits for both parties. The self-approach way to the customer is expected to make the company know the needs and desires of the customer. The better the company knows the customer, the better the company will market its products; it is similar to the customer side. Customers will feel cared for which ultimately customer loyalty is created for the company for a long time.

Customer trust is all knowledge possessed by the customer and all conclusions made by the customer about objects, attributes, and benefits. The object can be in the form of products, people, companies, and everything, which someone has trust and attitude. Whereas, attributes are characteristics or features that the objects may or may not have. In addition, benefits are positive results that give attributes to customers. Managers must realize that trust in objects, attributes, and benefits shows consumers' perceptions. Therefore, generally the trust of a customer is different from other customers (Sunarto, 2009: 153; Fian, 2016: 4).

Trust indicators consist of 3 components, among others: 1) Perception of integrity is a consumer perception that the company follows acceptable principles such as keeping promises and behaving ethically and honestly. 2) Perception of benevolence is based on the amount of trust in partnerships that have goals and motivations that are advantages for other organizations when new conditions arise; it is the conditions where commitment is not formed. 3) Perception of competence is the ability to solve problems faced by customers and fulfill all their needs. This ability refers to skills and characteristics that allow a group to have a dominant influence.

Consumer behavior in choosing a product and service can be affected by trust factor. It is because trust factors relate to the information they receive about certain products or services that they choose. For a bank, increasing trust will increase the customer's intention to use the bank because basically customer trust is caused by the satisfaction of the service they receive. 
Trust arises from a long process until both parties trust each other. If trust is established between customers and companies, the effort to build it will be easier because the relationship between the company and customers is reflected in the level of customer trust. If the level of customer trust is high, the company's relationship with the customer will be strong. There is one way that companies can do to build relationships with customers for example: all types of products produced by the company must have quality or perfection as they should or as what the company promised, so that customers do not feel tricked which can cause them to switch to competing products.

Customer trust in banks is an important factor that affects customer loyalty because in the banking world, trust is a very important factor.

Customer satisfaction is the feeling of being happy or disappointed that arises after comparing the performance (results) of a product and with the expectations that the customers have (Repi \& Baramuli, 2011: 66). Customer satisfaction is the result that buyers feel from the performance of companies that meet their expectations. Customers feel satisfied if their expectations are fulfilled and happy/joyful if their expectations are exceeded. Satisfied customers will be loyal longer, buy more products, are less sensitive to prices and give good comments about the company.

According to Lupyoadi (in Achsan et al., 2014: 7), there are five factors that must be considered by companies in determining customer satisfaction, among others:

1) Product quality, in which customers will feel satisfied if their results show that the product, they are using, is high quality. 2) Service quality, in which customers will feel satisfied if they get good or expected service. 3) Emotion, in which customers will feel proud of and get confidence that other people will be amazed at him/her when using products with certain brands that tend to have a higher level of satisfaction. Satisfaction is obtained not from the quality of the product but social or self-esteem that makes customers feel satisfied with a particular brand. 4) Price, in which products with the same quality but set a relatively cheap price will give a higher value to the customer. 5) Costs, in which customers tend to be satisfied with the product or service if they do not need to incur additional costs or do not need to waste time getting a product or service.

Hasan (2010: 85-86) stated that in business practice, one's expectations are always related to the following five things. 1) Inconsistency between actual expectations and ideals received will be an unpleasant personal experience. It will disappear when the customer gets another product that fulfills their identity needs. 2) Customers will tend to use services that are perceived as having conformity to the product image with the perceptions and expectations they want. 3) Customer behavior is affected by the type of business/ activity they have and the consistency of expectations for the image and quality of perceived product and service performance. 4) Good service will produce satisfaction and create a harmonious and smooth relationship. 5) By providing suitable products and pleasant services, customers will control external factors that can damage the company (bank) image (participating in defense).

Literally, loyal means faithful. Loyalty can be interpreted as loyalty. This loyalty appears without coercion, but it arises from one's own consciousness in the past. Businesses to create customer satisfaction are more likely to affect customer attitudes. Meanwhile, the concept of consumer loyalty further explains the behavior of buyers.

The commitment that accompanies repetitive purchases is a situation where customers do not want to move even though the product or service is being scarce in the market and consumers voluntarily recommend these products or services to colleagues, family or other consumers.

According to Griffin (in Arzena 2013: 3), loyalty shows the condition of a certain duration of time and requires that the purchase action occurs no less than twice. From the quote above, it is concluded that loyalty is an honest attitude of consumers to feel satisfaction from the results of the purchase of products or services provided by producers or sellers. So, the consumer will make repeated product purchases and create long-term relationships. 
According to Wiliam W. Zikmund (in Arzena 2013: 3) aspects that affect customer loyalty are as follows: 1) Satisfaction is a comparison between expectations before making a purchase and perceived performance. 2) Emotional Bond is when consumers feel a strong bond with other consumers who use the same product or service. 3) Trust is the willingness of someone to trust the company to carry out a function. 4) Choice reduction and habit (convenience) is the purchase of products regularly as an accumulation of experience at any time or repetition. 5) History with company (experience with the company) is a person's experience with the company that can shape behavior. Good company services will result in repetition of behavior in the company.

According to Griffin (in Arzena 2013: 4), the characteristics of loyal consumers include 1) Making repeat purchases regularly; 2) Purchasing across product lines and services; 3) Referring to other people (referrals). 4) Showing ignorance to interest in competitors.

Previous research that showed the correlation between service quality and customer satisfaction is the research conducted by Khan \& Fasih (2014) which showed that service quality, tangible, reliability, and empathy have a significant effect on customer satisfaction.

The same thing is also obtained from the research of Hidayat et al. (2015) which shows that service quality and customer trust have a significant effect on customer satisfaction and research conducted by Karim (2016) which shows that service quality has a significant effect on customer satisfaction. Previous research that showed the correlation between customer trust and customer satisfaction is a study conducted by Hidayat et al. (2015) which shows that service quality and customer trust have a significant effect on customer satisfaction.

Previous research that showed the correlation between service quality and customer loyalty is the research conducted by Khan (2014) which showed that service quality, tangible, reliability, and empathy have a significant effect on customer loyalty. The same thing is also obtained from the research conducted by Hidayat et al (2015) which showed that service quality, customer trust, religious commitment and customer satisfaction have a significant effect on customer loyalty and research conducted by Alshurideh (2017) which showed that service quality have a significant effect on customer loyalty.

Previous research that showed the correlation between customer satisfaction and customer loyalty is a research conducted by Rahmani-Nejad et al (2014) which showed that satisfaction, trust, commitment, and mental image have a significant effect on customer loyalty. The same thing is also obtained from the research conducted by Kashif et al (2015) which showed that customer satisfaction has a significant effect on customer loyalty and research conducted by Ayuni et al (2015) which showed that customer satisfaction has a significant effect on customer loyalty.

Previous research that showed the correlation between relationship closeness and customer loyalty is a research conducted by Fung So et al (2014) which showed that service brand evaluation and customer engagement have a significant effect on brand loyalty.

Previous research which showed the correlation between religiosity and customer loyalty is a research conducted by Hidayat et al (2015) which showed that service quality, customer trust, religious commitment, and customer satisfaction have a significant effect on customer loyalty.

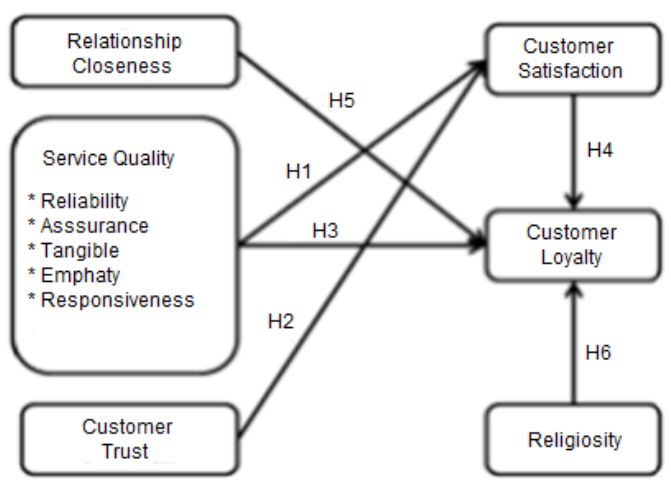

Figure 1 - Conceptual Framework 
Based on the above conceptual framework, the researchers formulate the research hypotheses as follows:

$\mathrm{H1}$ : Service quality has a significant and positive effect on customer satisfaction at Bank Jatim Syariah Surabaya.

$\mathrm{H} 2$ : Customer trust has a significant and positive effect on customer satisfaction at Bank Jatim Syariah Surabaya.

H3: Service quality has a significant and positive effect on customer loyalty at Bank Jatim Syariah Surabaya.

H4: Customer satisfaction has a significant and positive effect on customer loyalty at Bank Jatim Syariah Surabaya.

H5: Relationship closeness has a significant and positive effect on customer loyalty at Bank Jatim Syariah Surabaya.

H6: Religiosity has a significant and positive effect on customer loyalty at Bank Jatim Syariah Surabaya.

\section{METHODS OF RESEARCH}

In this research, the researchers apply quantitative approach because it is one type of research activity whose specifications are systematic, planned, and clearly structured from the beginning to the creation of research designs; including research objectives, research subject, research object, data sample, data source, and methodology. The method used in this research is an explanatory survey which is a method used to carry out causal correlation between variables through hypothesis testing.

The scope of this research analyzes the correlation between service quality, religiosity, relationship closeness, and customer trust on customer satisfaction and loyalty.

The variables of this research can be identified into 3 which include exogenous, intervening, and endogenous variables. 1) Exogenous variable is independent variable that is not affected by other variables in the model. 2) Intervening variable is endogenous variable and independent variable at the same time that affects another endogenous variable in a model. 3) Endogenous variable is dependent variable that is affected by other variables in a model.

Service quality is the expected level of excellence and control over the level of excellence to meet customer desires (Moha \& Loindong, 2016: 577). Trust is the belief that someone will find what he/she wants in others and not what he/she feared about. Religiosity is a condition in someone who encourages him/her to behave in accordance with the level of obedience to religion. The relationship closeness between employees and customers is measured by the openness and willingness for various information in providing services. Customer loyalty is a situation where the customer is positive about the product or service provider which is accompanied by a consistent repurchase pattern. Customer satisfaction is a response or feeling of the customer for the performance of the product or service they receive.

The sampling technique in this research applies purposive sampling by using judgment sampling in which the sampling is based on an assessment of the characteristics of the sample members that are adjusted to the research objectives.

The research population is customers of Bank Jatim Syariah Surabaya. Considerations in selecting respondents include: a) the age of customers is at least 17 years old, b) customers who open a savings account of at least 6 months, c) customers who are actively transacting at Bank Jatim Syariah under consideration that customers can still remember or perceive the service quality of Bank Jatim Syariah employees.

According to Hasan (2002: 82), primary data is data that is obtained or collected directly in the field by the person doing the research or the person who needs it". The primary data collection method of this research uses questionnaire as the research instrument.

This research is a type of quantitative research. According to Hasan (2002: 98), the quantitative method is an analysis that uses quantitative analysis tools. It means that the 
analysis tool uses models whose results are presented in the form of statistical and econometric model numbers and are explained and interpreted descriptively".

The data analysis technique of this research applies descriptive analysis and statistical analysis of Structural Equation Model (SEM) - AMOS.

\section{RESULTS AND DISCUSSION}

Respondents in this research are 200 customers of Bank Jatim Syariah Surabaya which were obtained using judgment sampling technique. The data collection obtained data about the identity of respondents to complete research information. From 200 customers of Bank Jatim Syariah Surabaya, the research respondents were 125 men or $63 \%$ and the rest 75 were women or $37 \%$. In addition, based on age, respondents aged between 17 years to under 24 years old were 28 respondents, aged between 24 years to under 29 years were 94 respondents, aged 29 years to under 34 years were 39 respondents, and aged over 34 years were 39 respondents. Based on the latest educational background, the majority of respondents were customers of Bank Jatim Syariah who had bachelor's degree as many as 160 respondents or $80 \%$ and the lowest educational background were those with junior high school education as many as 3 respondents or $1 \%$.

In terms of occupation, the majority of respondents are customers of Bank Jatim Syariah Surabaya who work as private employees as many as 104 respondents or $52 \%$; whereas, the lowest level is customers who are still school students as many as 3 respondents or by $1 \%$. In addition, in terms of income, the majority of respondents have income between 3 and 5 million as many as 106 respondents or $53 \%$ and the lowest level is customers who have income above 10 million as many as 15 respondents or $8 \%$.

Table 3 - Respondents' Response to Service Quality

\begin{tabular}{|c|c|c|c|c|c|c|c|c|}
\hline \multirow{2}{*}{ No } & \multirow{2}{*}{ Question Items } & \multicolumn{5}{|c|}{ Response } & \multirow{2}{*}{ Mean } & \multirow[b]{2}{*}{ Category } \\
\hline & & 1 & 2 & 3 & 4 & 5 & & \\
\hline 1 & SQ1 & 0 & 4 & 37 & 140 & 19 & 3.87 & Agree \\
\hline 2 & SQ2 & 0 & 0 & 32 & 131 & 37 & 4.03 & Agree \\
\hline 3 & SQ3 & 0 & 9 & 54 & 122 & 15 & 3.72 & Agree \\
\hline 4 & SQ4 & 3 & 23 & 25 & 114 & 35 & 3.78 & Agree \\
\hline \multicolumn{7}{|c|}{ Mean of Reliability } & 3.85 & Agree \\
\hline 5 & SQ5 & 0 & 0 & 18 & 133 & 49 & 4.16 & Agree \\
\hline 6 & SQ6 & 0 & 4 & 25 & 139 & 32 & 4.00 & Agree \\
\hline 7 & SQ7 & 0 & 0 & 6 & 148 & 46 & 4.20 & Agree \\
\hline 8 & SQ8 & 0 & 4 & 49 & 116 & 31 & 3.87 & Agree \\
\hline \multicolumn{7}{|c|}{ Mean of Assurance } & 4.06 & Agree \\
\hline 9 & SQ9 & 1 & 18 & 77 & 84 & 20 & 3.52 & Agree \\
\hline 10 & SQ10 & 0 & 9 & 75 & 90 & 26 & 3.67 & Agree \\
\hline 11 & SQ11 & 0 & 8 & 22 & 136 & 34 & 3.98 & Agree \\
\hline 12 & SQ12 & 0 & 10 & 44 & 115 & 31 & 3.84 & Agree \\
\hline \multicolumn{7}{|c|}{ Mean of Tangible } & 3.75 & Agree \\
\hline 13 & SQ13 & 0 & 0 & 20 & 121 & 59 & 4.20 & Agree \\
\hline 14 & SQ14 & 0 & 5 & 66 & 96 & 33 & 3.79 & Agree \\
\hline 15 & SQ15 & 0 & 1 & 58 & 106 & 35 & 3.88 & Agree \\
\hline \multicolumn{7}{|c|}{ Mean of Empathy } & 3.96 & Agree \\
\hline 16 & SQ16 & 0 & 8 & 25 & 136 & 31 & 3.95 & Agree \\
\hline 17 & SQ17 & 0 & 4 & 33 & 121 & 42 & 4.01 & Agree \\
\hline \multirow{2}{*}{\multicolumn{7}{|c|}{ Mean of Responsiveness }} & 3.98 & Agree \\
\hline & & \multicolumn{3}{|c|}{ Mean of Service Quality } & & & 3.92 & Agree \\
\hline
\end{tabular}

Source: the processed primary data.

The data showed that the majority of Surabaya Jatim Syariah Surabaya customers were active men in productive age who have obtained their latest educational background of bachelor's degree and worked as private employees with income above IDR 3 - 5 million.

The data analysis used in this research is a descriptive analysis that includes data on 200 respondents from Bank Jatim Syariah Surabaya customers on the indicators of question 
item. In addition, the statistical analysis of this research uses the Structural Equation Modeling (SEM) of AMOS version 22.0.

Based on 200 research questionnaires distributed to respondents who were all customers of Bank Jatim Syariah Surabaya, various concrete information regarding the responses of respondents to each research variable was obtained.

Based on the analysis on service quality, it appears that the customer provides a positive response to the 17 indicators of the statements under research. This is evidenced by the overall mean value of 3.92 from scale 5 . Based on the predetermined class intervals, customer evaluation is included in the agreed category on the service quality indicators that they feel when they are customers of Bank Jatim Syariah.

Customers provide positive responses to 3 indicators of statements under research. This is evidenced by the overall mean value of the religiosity indicator of 3.83 from scale 5 . Based on the predetermined class interval, the customer assessment is included in the agreed category on the religiosity indicators.

Table 4 - Respondents' Response to Religiosity Variable

\begin{tabular}{|c|c|c|c|c|c|c|c|c|}
\hline \multirow{2}{*}{ No } & \multirow{2}{*}{ Question Items } & \multicolumn{5}{|c|}{ Response } & \multirow{2}{*}{ Mean } & \multirow{2}{*}{ Category } \\
\hline & & 1 & 2 & 3 & 4 & 5 & & \\
\hline 1 & RL1 & 0 & 3 & 43 & 120 & 34 & 3.93 & Agree \\
\hline 2 & RL2 & 0 & 3 & 85 & 91 & 21 & 3.65 & Agree \\
\hline 3 & RL3 & 0 & 0 & 47 & 127 & 26 & 3.90 & Agree \\
\hline \multicolumn{7}{|c|}{ Mean of Religiosity } & 3.83 & Agree \\
\hline
\end{tabular}

Source: the processed primary data.

Customers provide positive responses to the 5 indicators of statements under research. This is evidenced by the overall mean value of the relationship closeness indicators of 3.76 from scale 5 . Based on the predetermined class intervals, the customer assessment is included in the agreed category of relationship closeness indicators.

Table 5 - Respondents' Response to Relationship Closeness Variable

\begin{tabular}{|c|c|c|c|c|c|c|c|c|}
\hline \multirow{2}{*}{ No } & \multirow{2}{*}{ Question Items } & \multicolumn{5}{|c|}{ Response } & \multirow{2}{*}{ Mean } & \multirow{2}{*}{ Category } \\
\hline & & 1 & 2 & 3 & 4 & 5 & & \\
\hline 1 & $\mathrm{RC1}$ & 0 & 17 & 54 & 109 & 20 & 3.66 & Agree \\
\hline 2 & $\mathrm{RC2}$ & 2 & 5 & 64 & 100 & 29 & 3.75 & Agree \\
\hline 3 & RC3 & 1 & 6 & 49 & 119 & 25 & 3.81 & Agree \\
\hline 4 & RC4 & 2 & 6 & 56 & 101 & 35 & 3.81 & Agree \\
\hline 6 & RC5 & 0 & 11 & 43 & 118 & 28 & 3.82 & Agree \\
\hline \multicolumn{7}{|c|}{ Mean of Relationship Closeness } & 3.76 & Agree \\
\hline
\end{tabular}

Source: the processed primary data.

Customers provide positive responses to the 2 indicators of statements under research. This is evidenced by the overall mean value of the trust indicators of 3.79 from scale 5 . Based on the predetermined class intervals, the customer assessment is included in the agreed category of the trust indicators.

Table 6 - Respondents' Response to Customer Trust Variable

\begin{tabular}{|c|c|c|c|c|c|c|c|c|}
\hline \multirow{2}{*}{ No } & \multirow{2}{*}{ Question Items } & 1 & 2 & 3 & 4 & 5 & \multirow{2}{*}{ Mean } & \multirow{2}{*}{ Category } \\
\hline 1 & CT1 & 4 & 37 & 18 & 109 & 32 & 3.93 & Agree \\
\hline 2 & CT2 & 1 & 12 & 32 & 125 & 30 & 3.65 & Agree \\
\hline \multicolumn{8}{|c|}{ Mean of Trust } \\
\hline
\end{tabular}

Source: the processed primary data.

Customers provide positive responses to the 3 indicators of statements under research. This is evidenced by the overall mean value of the customer loyalty indicators of 
3.89 from scale 5. Based on the predetermined class intervals, the customer assessment is included in the agreed category of the customer loyalty indicators.

Table 7 - Respondents' Response to Customer Loyalty Variable

\begin{tabular}{|c|c|c|c|c|c|c|c|c|}
\hline \multirow[b]{2}{*}{ No } & \multirow[b]{2}{*}{ Question Items } & \multicolumn{5}{|c|}{ Response } & \multirow[b]{2}{*}{ Mean } & \multirow[b]{2}{*}{ Category } \\
\hline & & 1 & 2 & 3 & 4 & 5 & & \\
\hline 1 & CL1 & 1 & 0 & 24 & 119 & 56 & 4.15 & Agree \\
\hline 2 & CL2 & 1 & 8 & 45 & 103 & 43 & 3.90 & Agree \\
\hline 3 & CL3 & 2 & 12 & 69 & 92 & 25 & 3.63 & Agree \\
\hline \multicolumn{7}{|c|}{ Mean of Customer Loyalty } & 3.89 & Agree \\
\hline
\end{tabular}

Source: the processed primary data.

Customers provide positive responses to the 3 indicators of statements under research. This is evidenced by the overall mean value of the customer satisfaction indicators of 3.75 from scale 5 . Based on the predetermined class intervals, the customer assessment is included in the agreed category of the customer satisfaction indicators.

Table 8 - Respondents' Response to Customer Satisfaction Variable

\begin{tabular}{|c|c|c|c|c|c|c|c|c|}
\hline \multirow{2}{*}{ No } & \multirow{2}{*}{ Question Items } & \multicolumn{5}{|c|}{ Response } & \multirow{2}{*}{ Mean } & \multirow{2}{*}{ Category } \\
\hline & & 1 & 2 & 3 & 4 & 5 & & \\
\hline 1 & CS1 & 0 & 2 & 45 & 128 & 25 & 3.88 & Agree \\
\hline 2 & CS2 & 0 & 6 & 67 & 99 & 28 & 3.75 & Agree \\
\hline 3 & CS3 & 1 & 21 & 63 & 86 & 29 & 3.61 & Agree \\
\hline \multicolumn{7}{|c|}{ Mean of Customer Satisfaction } & 3.75 & Agree \\
\hline
\end{tabular}

Source: the processed primary data.

The next step after doing a descriptive analysis is doing statistical analysis using Structural Equation Modeling (SEM). However, the estimation of the model in stages needs to be carried out first.

Validity Test in this research used Confirmatory Factor Analysis (CFA) to test the onedimensional variables in the research. The results of the CFA are as follows.

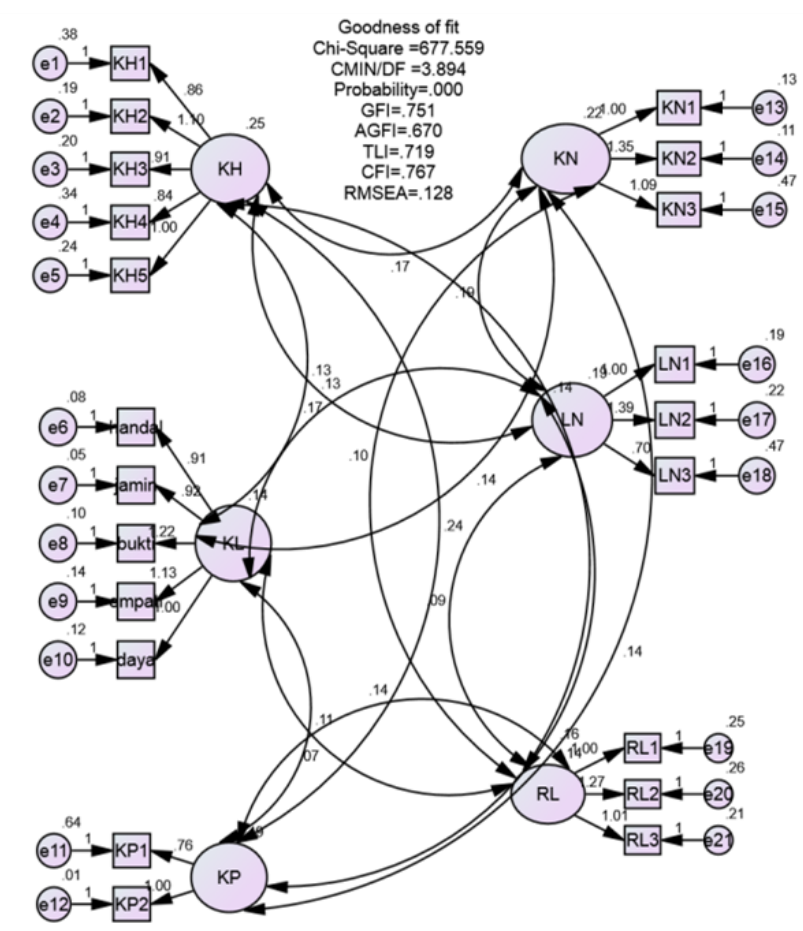

Figure 2 - CFA of Service Quality, Religiosity, Relationship Closeness, Customer Trust, Customer Satisfaction, and Customer Loyalty (Source: the processed primary data) 
Thus, the testing results of Goodness of Fit from the above model are presented in Table 9 as follows.

Table 9 - CFA Goodness of Fit of Service Quality, Religiosity, Relationship Closeness, Customer Trust, Customer Satisfaction, and Customer Loyalty

\begin{tabular}{|c|c|c|c|}
\hline Goodness of Fit & Cut-off Value & Estimate Results & Description \\
\hline $\mathrm{X}^{2}-$ Chi Square & 205.778 & 677.559 & Marginal \\
\hline CMIN/DF & $\leq 2.00$ & 3.894 & Marginal \\
\hline Probability & $\geq 0.05$ & 0.000 & Marginal \\
\hline GFI & $\geq 0.90$ & 0.751 & Marginal \\
\hline AGFI & $\geq 0.90$ & 0.670 & Marginal \\
\hline TLI & $\geq 0.95$ & 0.719 & Marginal \\
\hline CFI & $\geq 0.95$ & 0.767 & Marginal \\
\hline RMSEA & $\leq 0.08$ & 0.128 & \\
\hline
\end{tabular}

Source: the processed primary data.

Table 9 shows that out of the 8 (eight) criteria used to assess the feasibility of a model, all CFA testing outputs do not meet the criteria. Thus, the model proposed in Figure 2 is modified to be the model in Figure 3 as follows.

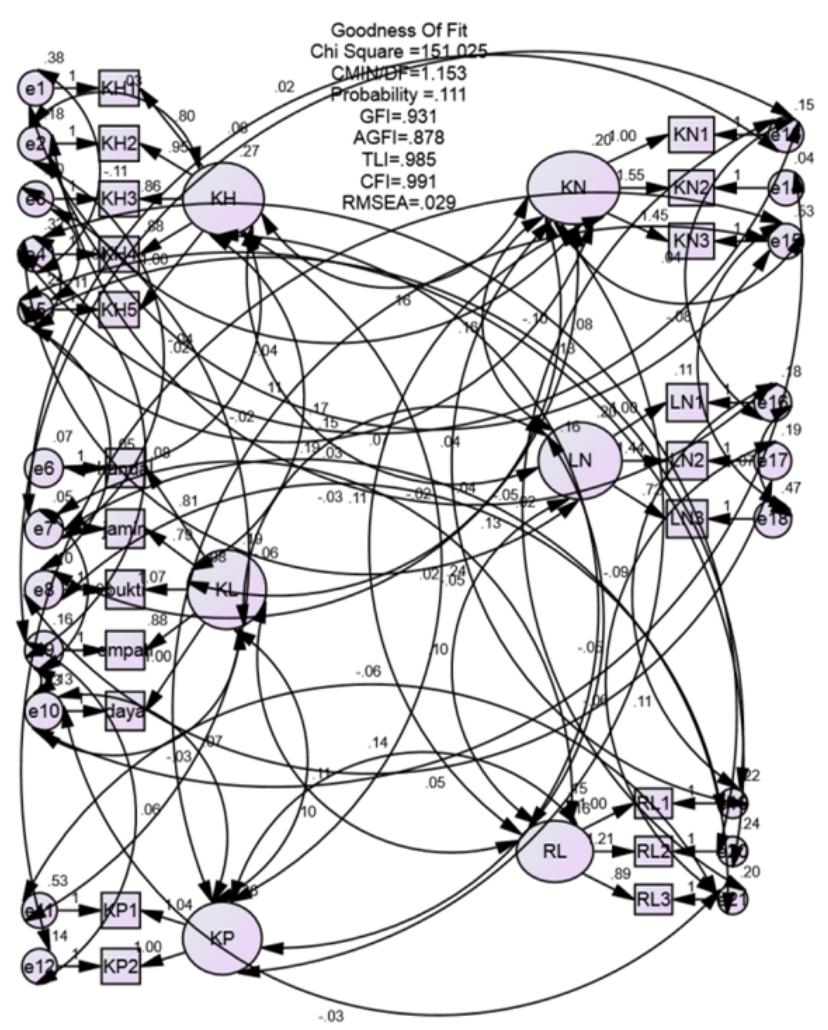

Figure 3 - CFA Service Quality, Religiosity, Relationship Closeness, Customer Trust, Customer

Satisfaction, and Customer Loyalty [after revision] (Source: the processed primary data)

Table 10 - CFA Goodness of Fit of Service Quality, Religiosity, Relationship Closeness, Customer Trust, Customer Satisfaction, and Customer Loyalty (after revision)

\begin{tabular}{|c|c|c|c|}
\hline Goodness of Fit & Cut-off Value & Estimate Results & Description \\
\hline$X^{2}-$ Chi Square & 158.711 & 151.025 & Good \\
\hline CMIN/DF & $\leq 2.00$ & 0.153 & Good \\
\hline Probability & $\geq 0.05$ & 0.931 & Good \\
\hline GFI & $\geq 0.90$ & 0.878 & Good \\
\hline AGFI & $\geq 0.90$ & 0.985 & Good \\
\hline TLI & $\geq 0.95$ & 0.991 & Good \\
\hline CFI & $\geq 0.95$ & 0.029 & Good \\
\hline RMSEA & $\leq 0.08$ & & Good \\
\hline
\end{tabular}

Source: the processed primary data. 
Table 11 shows that the loading factor value of each indicator above has a cut-off value which indicates that the indicator is valid.

Table 11 - Regression Weights of Service Quality, Religiosity, Relationship Closeness, Customer Trust, Customer Satisfaction, and Customer Loyalty

\begin{tabular}{|c|c|c|c|c|}
\hline Indicators & Probability $(\mathrm{P})$ & Loading Factor & Cut-off Value & Description \\
\hline $\mathrm{RC5} \leftarrow \mathrm{RC}$ & 0.000 & 0.730 & $>0.40$ & Valid \\
\hline $\mathrm{RC} 4 \leftarrow \mathrm{RC}$ & 0.000 & 0.627 & $>0.40$ & Valid \\
\hline $\mathrm{RC} 3 \leftarrow \mathrm{RC}$ & 0.000 & 0.708 & $>0.40$ & Valid \\
\hline $\mathrm{RC} 2 \leftarrow \mathrm{RC}$ & 0.000 & 0.712 & $>0.40$ & Valid \\
\hline $\mathrm{RC} 1 \leftarrow \mathrm{RC}$ & 0.000 & 0.558 & $>0.40$ & Valid \\
\hline Responsiveness $\leftarrow \mathrm{SQ}$ & 0.000 & 0.858 & $>0.40$ & Valid \\
\hline Empathy $\leftarrow$ SQ & 0.000 & 0.683 & $>0.40$ & Valid \\
\hline Tangible $\leftarrow$ SQ & 0.000 & 0.829 & $>0.40$ & Valid \\
\hline Assurance $\leftarrow$ SQ & 0.000 & 0.828 & $>0.40$ & Valid \\
\hline Reliability $\leftarrow$ SQ & 0.000 & 0.793 & $>0.40$ & Valid \\
\hline $\mathrm{CT} 2 \leftarrow \mathrm{CT}$ & 0.000 & 0.852 & $>0.40$ & Valid \\
\hline CT1 $\leftarrow$ CT & 0.000 & 0.652 & $>0.40$ & Valid \\
\hline $\mathrm{CS} 1 \leftarrow \mathrm{CS}$ & 0.000 & 0.756 & $>0.40$ & Valid \\
\hline $\mathrm{CS} 2 \leftarrow \mathrm{CS}$ & 0.000 & 0.963 & $>0.40$ & Valid \\
\hline CS3 $\leftarrow$ CS & 0.000 & 0.760 & $>0.40$ & Valid \\
\hline $\mathrm{CL1} \leftarrow \mathrm{CL}$ & 0.000 & 0.725 & $>0.40$ & Valid \\
\hline $\mathrm{CL} 2 \leftarrow \mathrm{CL}$ & 0.000 & 0.830 & $>0.40$ & Valid \\
\hline CL3 $\leftarrow$ CL & 0.000 & 0.426 & $>0.40$ & Valid \\
\hline $\mathrm{RL} 1 \leftarrow \mathrm{RL}$ & 0.000 & 0.651 & $>0.40$ & Valid \\
\hline $\mathrm{RL} 2 \leftarrow \mathrm{RL}$ & 0.000 & 0.706 & $>0.40$ & Valid \\
\hline $\mathrm{RL} 3 \leftarrow \mathrm{RL}$ & 0.000 & 0.629 & $>0.40$ & Valid \\
\hline
\end{tabular}

Source: the processed primary data.

Reliability test in this research uses construct reliability. The equation of construct reliability is as follows.

$$
\mathrm{CR}=\frac{\left(\sum \text { Standardized Loading }\right)^{2}}{\left(\sum \text { Standardized Loading }\right)^{2}+\sum \varepsilon \mathrm{j}}
$$

The limit value used to assess the acceptable level of reliability is $>0.70$. The summary of the results of construct reliability test in Table 12 is as follows.

Table 12 - Construct Reliability

\begin{tabular}{|c|c|c|c|c|c|c|}
\hline Variables & Constructs & SFL Square & Error (EJ) & Construct Reliability & Cut-off Value & Description \\
\hline \multirow{5}{*}{$\mathrm{RC}$} & RC5 & 0.533 & 0.467 & \multirow{5}{*}{0.802} & \multirow{5}{*}{$>0.70$} & \multirow{5}{*}{ Reliable } \\
\hline & $\mathrm{RC} 4$ & 0.393 & 0.607 & & & \\
\hline & RC3 & 0.501 & 0.499 & & & \\
\hline & $\mathrm{RC2}$ & 0.507 & 0.493 & & & \\
\hline & $\mathrm{RC} 1$ & 0.311 & 0.689 & & & \\
\hline \multirow{5}{*}{$\mathrm{SQ}$} & Responsiveness & 0.736 & 0.264 & \multirow{5}{*}{0.899} & \multirow{5}{*}{$>0.70$} & \multirow{5}{*}{ Reliable } \\
\hline & Empathy & 0.466 & 0.534 & & & \\
\hline & Tangible & 0.687 & 0.313 & & & \\
\hline & Assurance & 0.686 & 0.314 & & & \\
\hline & Reliability & 0.629 & 0.371 & & & \\
\hline \multirow{2}{*}{ CT } & CT2 & 0.726 & 0.274 & \multirow{2}{*}{0.727} & \multirow{2}{*}{$>0.70$} & \multirow{2}{*}{ Reliable } \\
\hline & CT1 & 0.425 & 0.575 & & & \\
\hline \multirow{3}{*}{ CS } & CS1 & 0.572 & 0.428 & \multirow{3}{*}{0.869} & \multirow{3}{*}{$>0.70$} & \multirow{3}{*}{ Reliable } \\
\hline & CS2 & 0.927 & 0.073 & & & \\
\hline & CS3 & 0.578 & 0.422 & & & \\
\hline \multirow{3}{*}{$C L$} & CL1 & 0.526 & 0.474 & \multirow{3}{*}{0.710} & \multirow{3}{*}{$>0.70$} & \multirow{3}{*}{ Reliable } \\
\hline & CL2 & 0.686 & 0.311 & & & \\
\hline & CL3 & 0.181 & 0.819 & & & \\
\hline \multirow{3}{*}{$R L$} & RL1 & 0.424 & 0.576 & \multirow{3}{*}{0.701} & \multirow{3}{*}{$>0.70$} & \multirow{3}{*}{ Reliable } \\
\hline & RL2 & 0.498 & 0.502 & & & \\
\hline & RL3 & 0.396 & 0.604 & & & \\
\hline
\end{tabular}

Source: the processed primary data. 
Table 12 above shows that the questionnaire from the variables of Service Quality, Religiosity, Relationship Closeness, Trust, Customer Satisfaction and Customer Loyalty has consistent and stable respondents' answers from time to time on each statement. This can be seen from the construct reliability value which is more than the cut-off value.

The next step is to test assumptions that include the fulfillment of the use of SEM. In this SEM equation model, there are several assumptions that must be fulfilled, among others:

The number of research samples was 200 respondents, all of whom were customers of Bank Jatim Syariah Surabaya.

Evaluation of normality distribution is carried by skewness value from the data which is usually presented in descriptive statistics. The statistical value for testing normality distribution is called z-value. If the $z$-value is greater than the critical value, it is assumed that the data distribution is not normal. Critical values can be determined based on the significance level of $0.01(1 \%)$ which is equal to \pm 2.58 .

Table 13 - Data Normality

\begin{tabular}{|c|c|c|c|}
\hline Variables & Cut-off Value & C.R. & Description \\
\hline RL3 & \pm 2.58 & -.462 & Normal Distribution \\
\hline RL2 & \pm 2.58 & -1.376 & Normal Distribution \\
\hline RL1 & \pm 2.58 & 1.096 & Normal Distribution \\
\hline CL3 & \pm 2.58 & -1.037 & Normal Distribution \\
\hline CL2 & \pm 2.58 & -.404 & Normal Distribution \\
\hline CL1 & \pm 2.58 & -1.224 & Normal Distribution \\
\hline CS3 & \pm 2.58 & -1.468 & Normal Distribution \\
\hline CS2 & \pm 2.58 & -.982 & Normal Distribution \\
\hline CS1 & \pm 2.58 & -.681 & Normal Distribution \\
\hline CT1 & \pm 2.58 & -1.092 & Normal Distribution \\
\hline CT2 & \pm 2.58 & 2.484 & Normal Distribution \\
\hline Reliability & \pm 2.58 & 2.300 & Normal Distribution \\
\hline Assurance & \pm 2.58 & 1.354 & Normal Distribution \\
\hline Tangible & \pm 2.58 & -.279 & Normal Distribution \\
\hline Empathy & \pm 2.58 & -1.316 & Normal Distribution \\
\hline Responsiveness & \pm 2.58 & 1.688 & Normal Distribution \\
\hline RC1 & \pm 2.58 & .019 & Normal Distribution \\
\hline RC2 & \pm 2.58 & -1.335 & Normal Distribution \\
\hline RC3 & \pm 2.58 & -.054 & Normal Distribution \\
\hline RC4 & \pm 2.58 & -1.430 & Normal Distribution \\
\hline RC5 & \pm 2.58 & 1.009 & Normal Distribution \\
\hline
\end{tabular}

Source: the processed primary data.

Based on the results of normality test data, all indicators are normally distributed because they have met the normality requirements, i.e. c.r \pm 2.58 at the $\alpha 0.01$ significance level. Therefore, the assumption of normality has been fulfilled so that this data is feasible to be used in the next estimates.

Data is considered normal if the data is symmetrical with its skewness value and has an ideal slope. Ghozali (in Dewi 2014: 53) argued that the data is considered to have a normal distribution if the value of the critical ratio skewness is below the absolute value of 2.58 .

Testing of univariate outliers can be performed by determining threshold values that will be categorized as outliers by converting the value of research data on a standard score or what so-called z-score, which has a zero average with a standard deviation of one. According to Ferdinand (2002: 98), for large samples (above 80), evaluations are carried out using the basis that the observation that has $z$-score $\geq 3.0$ will be categorized as outliers.

Table 14 below shows the $z$-score value $\geq 3.0$. Therefore, it is concluded that there are univariate outliers. The number of observations for the value of $\geq 3.0$ is 15 observations so that the number of respondents used for the next test is 185 people. 
Table 14 - Univariate Outlier

\begin{tabular}{|c|c|c|c|c|c|}
\hline$n / n$ & $\mathrm{~N}$ & Min & Max & Mean & Std. Deviation \\
\hline Zscore()SQ1 & 200 & -3.18451 & 1.92433 & .0000000 & 1.00000000 \\
\hline Zscore(SQ2) & 200 & -1.74229 & 1.65730 & .0000000 & 1.00000000 \\
\hline Zscore(SQ3) & 200 & -2.56800 & 1.92412 & .0000000 & 1.00000000 \\
\hline Zscore(SQ4) & 200 & -3.01236 & 1.32978 & .0000000 & 1.00000000 \\
\hline Zscore(SQ5) & 200 & -2.06600 & 1.51149 & .0000000 & 1.00000000 \\
\hline Zscore(SQ6) & 200 & -3.29399 & 1.65938 & .0000000 & 1.00000000 \\
\hline Zscore(SQ7) & 200 & -2.55200 & 1.70134 & .0000000 & 1.00000000 \\
\hline Zscore(SQ8) & 200 & -2.74114 & 1.65635 & .0000000 & 1.00000000 \\
\hline Zscore(SQ9) & 200 & -3.09508 & 1.81774 & .0000000 & 1.00000000 \\
\hline Zscore(SQ10) & 200 & -2.19449 & 1.75995 & .0000000 & 1.00000000 \\
\hline Zscore(SQ11) & 200 & -2.97884 & 1.53456 & .0000000 & 1.00000000 \\
\hline Zscore(SQ12) & 200 & -2.47313 & 1.57013 & .0000000 & 1.00000000 \\
\hline Zscore(SQ13) & 200 & -1.99508 & 1.34397 & .0000000 & 1.00000000 \\
\hline Zscore(SQ14) & 200 & -2.40355 & 1.63603 & .0000000 & 1.00000000 \\
\hline Zscore(SQ15) & 200 & -2.72994 & 1.63796 & .0000000 & 1.00000000 \\
\hline Zscore(SQ16) & 200 & -2.94074 & 1.58348 & .0000000 & 1.00000000 \\
\hline Zscore(SQ17) & 200 & -2.96505 & 1.47143 & .0000000 & 1.00000000 \\
\hline Zscore(RL1) & 200 & -2.89684 & 1.61772 & .0000000 & 1.00000000 \\
\hline Zscore(RL2) & 200 & -2.40716 & 1.96949 & .0000000 & 1.00000000 \\
\hline Zscore(RL3) & 200 & -1.50054 & 1.85263 & .0000000 & 1.00000000 \\
\hline Zscore(RC1) & 200 & -2.14773 & 1.73371 & .0000000 & 1.00000000 \\
\hline Zscore(RC2) & 200 & -3.56482 & 1.62982 & .0000000 & 1.00000000 \\
\hline Zscore(RC3) & 200 & -3.96896 & 1.69088 & .0000000 & 1.00000000 \\
\hline Zscore(RC4) & 200 & -3.53362 & 1.50541 & .0000000 & 1.00000000 \\
\hline Zscore(RC5) & 200 & -2.46195 & 1.60739 & .0000000 & 1.00000000 \\
\hline Zscore(CT1) & 200 & -2.58176 & 1.33000 & .0000000 & 1.00000000 \\
\hline Zscore(CT2) & 200 & -3.75899 & 1.50755 & .0000000 & 1.00000000 \\
\hline Zscore(CL1) & 200 & -4.81795 & 1.30981 & .0000000 & 1.00000000 \\
\hline Zscore(CL2) & 200 & -3.62680 & 1.38432 & .0000000 & 1.00000000 \\
\hline Zscore(CL3) & 200 & -3.22165 & 1.67820 & .0000000 & 1.00000000 \\
\hline Zscore(CS1) & 200 & -3.05990 & 1.82292 & .0000000 & 1.00000000 \\
\hline Zscore(CS2) & 200 & -2.39100 & 1.71690 & .0000000 & 1.00000000 \\
\hline Zscore(CS3) & 200 & -2.96321 & 1.58683 & .0000000 & 1.00000000 \\
\hline Valid (listwise) & 200 & & & & \\
\hline
\end{tabular}

Source: the processed primary data.

Outliers are observations or data that have unique characteristics that look very different from other observations. It appears in the form of extreme values on a single variable or combination variable. The mahalanobis distance for each observation can be calculated and will show the distance of an observation from the mean of all variables in a multidimensional space.

Calculating the mahalanobis distance is based on the chi square value at the free degree of the indicator used in each variable. There are 10 indicators, therefore, the value of chi squared is $X^{2}$ table $(0.001: 33)=63.8701$.

Table 15 - Multivariate Outlier

\begin{tabular}{|c|c|c|c|c|c|}
\hline & $\mathrm{N}$ & Min & Max & Mean & Std. Deviation \\
\hline Predicted Value & 185 & 11.59 & 186.22 & 102.24 & 33.573 \\
\hline Std. Predicted Value & 185 & -2.700 & 2.501 & .000 & 1.000 \\
\hline Standard Error of Predicted Value & 185 & 7.455 & 33.491 & 21.811 & 5.867 \\
\hline Adjusted Predicted Value & 185 & 11.41 & 211.72 & 103.12 & 36.462 \\
\hline Residual & 185 & -142.477 & 94769 & .000 & 47.718 \\
\hline Std. Residual & 185 & -2.705 & 1.799 & .000 & .906 \\
\hline Stud. Residual & 185 & -2.935 & 1.946 & -.007 & .996 \\
\hline Deleted Residual & 185 & -167.781 & 112.056 & -.873 & 58.024 \\
\hline Stud. Deleted Residual & 185 & -3.013 & 1.964 & -.008 & 1.002 \\
\hline Mahal. Distance & 185 & 2.691 & 73.387 & 32.822 & 16.101 \\
\hline Cook's Distance & 185 & .000 & .065 & .006 & .010 \\
\hline Centered Leverage Value & 185 & .015 & .399 & .178 & .090 \\
\hline
\end{tabular}

Source: the processed primary data.

The processed data shows that there are still 7 data outliers i.e. data 59, 77, 54, 99, 11 , 80 and 37 which have an mahalonobi distance value above 63.8701. Then the data must be discarded as many as 7 observations. So, the data for the next stage of analysis is 178 data.

The results of processing data using AMOS can be seen in Figure 4 below. 


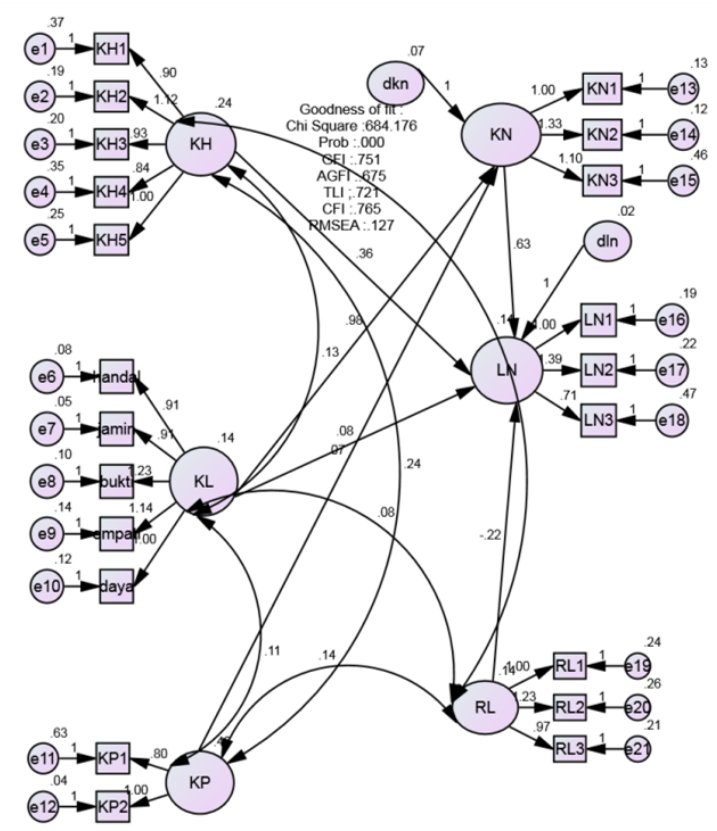

Figure 4 - Structural Equation Model (Source: the processed primary data)

Thus, the results of the Goodness of Fit test from the above model found in Table 16 are as follows:

Table 16 - Goodness of Fit of Structural Equation Model

\begin{tabular}{|c|c|c|c|}
\hline Goodness of Fit & Cut-off Value & Estimate Results & Description \\
\hline$X^{2}-$ Chi Square & 209.042 & 684.176 & Marginal \\
\hline CMIN/ DF & $\leq 2.00$ & 3.865 & Marginal \\
\hline Probability & $\geq 0.05$ & 0.000 & Marginal \\
\hline GFI & $\geq 0.90$ & 0.751 & Marginal \\
\hline AAGFI & $\geq 0.90$ & 0.721 & Marginal \\
\hline TLI & $\geq 0.95$ & 0.765 & Marginal \\
\hline CFI & $\geq 0.95$ & 0.127 & Marginal \\
\hline
\end{tabular}

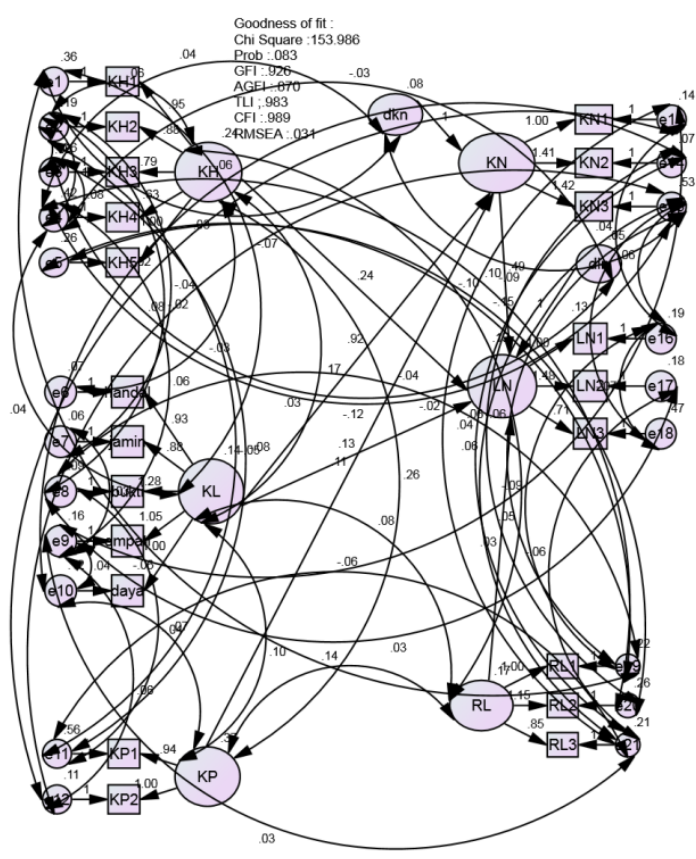

Figure 5 - Structural Equation Model [after revision] (Source: the processed primary data) 
SEM analysis is intended to test the models that have been developed based on theory simultaneously. Based on the results of the model feasibility test, the probability value is $<5 \%$ which is equal to 0.000 . This shows that there is a mismatch of the model developed so that it requires modification of the model.

Based on the initial model, the population covariance variant matrix is not the same as the estimate model covariance variant matrix. So, modification of the model is carried out by correlating between residuals.

Thus, the results of the Goodness of Fit test from the above model are obtained in Table 17 as follows:

Table 17 - Goodness of Fit of Structural Equation Model (after revision)

\begin{tabular}{|c|c|c|c|}
\hline Goodness of Fit & Cut-off Value & Estimate Results & Description \\
\hline$X^{2}-$ Chi Square & 158.711 & 153.986 & Good \\
\hline CMIN/ DF & $\leq 2.00$ & 1.175 & Good \\
\hline Probability & $\geq 0.05$ & 0.083 & Good \\
\hline GFI & $\geq 0.90$ & 0.926 & Good \\
\hline AAGFI & $\geq 0.90$ & 0.870 & Good \\
\hline TLI & $\geq 0.95$ & 0.983 & Good \\
\hline CFI & $\geq 0.95$ & 0.989 & Good \\
\hline
\end{tabular}

Source: the processed primary data.

The modified structural model results in a decrease in the X2 value with a probability of 0.083 in which this value is greater than $5 \%$. Thus, it gets the same population covariant variant matrix as the estimate covariant variant of the model. In addition to this probability value, it can be seen that all the criteria have met the specified cut-off value. After obtaining the appropriate model, then the significance of the model can be seen by comparing the probability value of each causality relationship with $\leq 5 \%$. The value of loading factor and significance is presented in Table 18 below.

Table 18 - Weight Regression of SEM

\begin{tabular}{|c|c|c|c|}
\hline Variables & Std. Estimate & P-Value & Description \\
\hline $\mathrm{CS} \leftarrow \mathrm{SQ}$ & 0.733 & 0.000 & Significant \\
\hline $\mathrm{CS} \leftarrow \mathrm{CT}$ & 0.142 & 0.028 & Significant \\
\hline $\mathrm{CL} \leftarrow \mathrm{SQ}$ & 0.107 & 0.414 & Not Significant \\
\hline $\mathrm{CL} \leftarrow \mathrm{CS}$ & 0.524 & 0.000 & Significant \\
\hline $\mathrm{CL} \leftarrow \mathrm{RC}$ & 0.270 & 0.032 & Significant \\
\hline $\mathrm{CL} \leftarrow \mathrm{RL}$ & 0.027 & 0.784 & Not Significant \\
\hline
\end{tabular}

Source: the processed primary data.

The structural model that has been obtained shows that the correlation between customer satisfaction and service quality is 0.733 while the loading value between customer satisfaction and customer trust is 0.142 . This shows that the correlation between customer satisfaction and service quality is greater than the correlation between customer satisfaction and customer trust.

The correlation between customer loyalty and relationship closeness is 0.027 , the loading value between customer loyalty and customer satisfaction is 0.524 , the loading value between customer loyalty and service quality is 0.107 and the loading value between customer loyalty and religiosity is 0.027 . It shows that the correlation between customer loyalty and customer satisfaction is greater than the correlation between customer loyalty and other variables.

Hypothesis Testing:

Hypothesis I. The hypothesis which mentions that "service quality has a significant and positive effect on customer satisfaction at Bank Jatim Syariah" is accepted which is evidenced by $p$-value $<0.05$. 
Hypothesis II. The hypothesis which mentions that "customer trust has a significant and positive effect on customer satisfaction at Bank Jatim Syariah" is accepted which is evidenced by $p$-value $<0.05$.

Hypothesis III. The hypothesis which mentions that "service quality has a significant and positive effect on customer loyalty at Bank Jatim Syariah" is rejected which is evidenced by $p$-value $>0.05$.

Hypothesis IV. The hypothesis which mentions that "customer satisfaction has a significant and positive effect on customer loyalty at Bank Jatim Syariah" is accepted which is evidenced by $p$-value $<0.05$.

Hypothesis V. The hypothesis which mentions that "relationship closeness has a significant and positive effect on customer loyalty at Bank Jatim Syariah" is accepted which is evidenced by $\mathrm{p}$-value $<0.05$.

Hypothesis VI. The hypothesis which mentions that "religiosity has a significant and positive effect on customer loyalty at Bank Jatim Syariah" is rejected which is evidenced by p-value $>0.05$.

\section{DISCUSSION OF RESULTS}

The findings showed that service quality has a significant and positive effect on customer satisfaction at Bank Jatim Syariah Surabaya. This is in line with the research conducted by Khan et al (2014), Rahmani-Nejad et al (2014), Hidayat et al (2015), and Karim (2016) who stated that service quality has a significant and positive effect on customer satisfaction.

The research findings showed that customer trust has a significant and positive effect on customer satisfaction at Bank Jatim Syariah Surabaya. This is in accordance with the research conducted by Hidayat et al (2015) who stated that customer trust has a positive effect on customer satisfaction.

The research findings indicate that service quality has no significant positive effect on customer loyalty at Bank Jatim Syariah Surabaya. This is different from the research conducted by Khan et al (2014), Kashif et al (2015), Hidayat et al (2015), Ayuni et al (2015), and Alshurideh (2017) who stated that service quality has a positive effect on loyalty customer.

The research findings showed that customer satisfaction has a significant and positive effect on customer loyalty at Bank Jatim Syariah Surabaya. This is in line with the research conducted by Hidayat et al (2015), Rahmani-Nejad et al (2014), Khan et al (2014), Kashif et al (2015), Ayuni et al (2015) who stated that customer satisfaction has a positive effect on loyalty customer.

The research findings indicated that relationship closeness has a positive and significant effect on customer loyalty at Bank Jatim Syariah Surabaya. This is in accordance with the research conducted by Fung So et al (2014) who stated that customer relationship closeness has a positive effect on customer loyalty.

The research findings showed that religiosity does not have a positive and significant effect on customer loyalty at Bank Jatim Syariah Surabaya. This is different from the research conducted by Rahmani-Nejad et al (2014) who stated that religiosity has a positive effect on customer loyalty. On the other hand, these research findings are in line with the research conducted by Hidayat et al (2015) and Ayuni et al (2015) who stated that religiosity has a positive and not significant effect on customer loyalty.

\section{CONCLUSION AND SUGGESTIONS}

Based on the analysis results and testing of the research hypotheses that have been carried out previously, the following conclusions can be drawn from this research: 1) The analysis results of service quality indicated that the assurance factor is more decisive than other factors. On the other hand, the tangible is a non-dominant factor in which customers override physical appearance and prioritize security in conducting transactions at Bank Jatim 
Syariah Surabaya. 2) Quality service has a significant and positive effect on customer satisfaction at Bank Jatim Syariah Surabaya. It means that if Bank Jatim Syariah always maintains and improves the quality of its services, customers will feel more satisfied because their expectations have been fulfilled. 3) Customer trust has a significant and positive effect on customer satisfaction at Bank Jatim Syariah Surabaya. It means that if Bank Jatim Syariah continues to maintain customer trust, customers will feel more satisfied and it is possible that they will increase their savings balance and increase the intensity of transactions at Bank Jatim Syariah. 4) Quality service does not have a significant and positive effect on customer loyalty at Bank Jatim Syariah Surabaya. It means that Bank Jatim Syariah does not only have to maintain and keep the quality of its services to maintain customer loyalty but also must take other steps. 5) Customer satisfaction has a significant and positive effect on customer loyalty at Bank Jatim Syariah Surabaya. It means that customer loyalty will be formed if the customer is satisfied with the services that Bank Jatim Syariah provides; especially if the bank can provide services that exceed customer expectations. 6) The closeness of the relationship has a significant and positive effect on customer loyalty at Bank Jatim Syariah Surabaya. It means that the emotional relationship that exists between the employees of Bank Jatim Syariah Surabaya and its customers will indirectly have an impact on customer loyalty. This is very beneficial for Bank Jatim Syariah. If the bank is able to establish the bond, the customer will not move to another bank even though with the lure of high profit sharing. 7) Religiosity does not have a significant and positive effect on customer loyalty at Bank Jatim Syariah Surabaya. It means that religious factors do not always guarantee that customers will remain loyal to Bank Jatim Syariah.

This research has been attempted and carried out in accordance with scientific procedures. However, it still has limitations, among others: 1) Factors affecting customer loyalty and satisfaction in this research consist of only 4 variables which include service quality, religiosity, relationship closeness, and customer trust; whereas, there are still many other factors affecting customer loyalty and satisfaction. 2) The limitations in using a questionnaire are that sometimes the answers given by the respondent do not indicate the real situation. 3) After the revision, the Adjusted Goodness of Fit Index (AGFI) in the SEM is still at a value of 0.870 which should be value equal to or greater than 0.90 .

Based on the analysis results of the research that has been carried out, the researcher will then present some suggestions as follows. 1) For STIE Perbanas Surabaya, these research findings are expected to be able to give contribution regarding customer loyalty and satisfaction and also as a reference for other students who wish to deepen their research references related to customer loyalty and satisfaction. 2) For Bank Jatim Syariah Surabaya, these research findings have several things that must be addressed including: a) In terms of determinants of service quality, the assurance factors of "employees act professionally, employees offer safe investment products, employees are polite, and employees have good product knowledge" should be maintained because respondents respond to this very well. However, in the tangible factor in the form of "modern equipment in banking hall, the offered facilities are attractive, the employees' explanation for Bank Jatim Syariah products is easy to understand, and office buildings are good" should be evaluated immediately and repaired continuously because customers give less positive responses against this. b) In terms of relationship closeness, customer involvement in terms of "repairs and product development of Bank Jatim Syariah" is very necessary because constructive criticism and suggestions from customers will clarify the picture of the good and bad products and services provided by Bank Jatim Syariah. c) In terms of customer trust, employees of Bank Jatim Syariah, especially service assistants are expected to always provide solutions to the problems faced by customers related to the products and services. d) In terms of customer loyalty, high profit-sharing offers and the lure of attractive souvenirs from other banks are still attractive to the existing customers of Bank Jatim Syariah to move to those banks. It must be taken into consideration seriously by the management of Bank Jatim Syariah. The concrete step is to benchmark the competing banks regarding the products and services. e) In terms of customer satisfaction, the services provided by Bank Jatim Syariah have not yet made customers satisfied that customers still consider that services provided by other banks are 
better than Bank Jatim Syariah. Regarding this reason, the management of Bank Jatim Syariah should evaluate the implementation of standard services carried out in the Surabaya Syariah Branch. 3) Future research is expected to expand the scope of determinants of customer satisfaction and loyalty found in the references of previous research articles. Some aspects that could not be conducted by the authors in this research include: a) Perception, Identification, Enthusiasm, Attention, Absorption and Interaction which were discussed in the research article of Fung So, et al (2014). b) Mental imagery which was discussed in the research article of Rahmani-Nejad et al (2014). c) Sincerity, Personalization, and Formality which were discussed in the Kashif et al (2015) research. d) Sharia principles which was discussed in the research of Hidayat et al (2015) e) Compliance and Brand Image which were discussed in the research of Ayuni et al (2015).

\section{REFERENCES}

1. Akbar, M. M., \& Parvez, N. (2009). Impact of service quality, trust, and customer satisfaction on customers loyalty. ABAC Journal, 29(1).

2. Ashdaq, M., Maupa, H., Amar, M. Y., \& Nursyamsi, I. (2015). Analysis of Service Quality On Pilgrims Satisfaction And Image Of Hajj And Umrahs Travel Agents In South Sulawesi Province, Indonesia. International Journal of Research In Social Sciences, 5(6).

3. Bentler, P. M., \& Chou, Chih Ping. (1987). Practical issues in structural modeling. Sociological Methods and Research, 16, 78-117.

4. Bloemer, J., De Ruyter, K., \& Peeters, P. (1998). Investigating drivers of bank loyalty: the complex relationship between image, service quality and satisfaction. International Journal of bank marketing, 16(7), 276-286.

5. Edgar, M., \& Galia, F. (2009). Why and How Service Quality Perceptions Impact Cunsomer Responses. Journal of Managing Service Quality. 19(4): 474-485.

6. Ferrinadewi, E. (2008). Merek dan Psikologi Konsumen, Implikasi pada Strategi Pemasaran. Yogyakarta: Graha Ilmu.

7. Hair, J. F., Black, W. C., Babin, B., Anderson, R. E., \& Tatham, R. L. (2010). Multivariate Data Analysis (6th). New Jersey: Pearson Prentice Hall.

8. Izogo, E. E., \& Ogba, I. E. (2015). Service quality, customer satisfaction and loyalty in automobile repair services sector. International Journal of Quality \& Reliability Management, 32(3), 250-269.

9. Kashif, M., Wan Shukran, S. S., Rehman, M. A., \& Sarifuddin, S. (2015). Customer satisfaction and loyalty in Malaysian Islamic banks: a PAKSERV investigation. International Journal of Bank Marketing, 33(1), 23-40.

10. Kheng, L. L., Mahamad, O., \& Ramayah, T. (2010). The impact of service quality on customer loyalty: A study of banks in Penang, Malaysia. International journal of marketing studies, 2(2), 57.

11. Kotler, P., \& Amstrong, G. (2008). Prinsip-prinsip Pemasaran (Vol. Edisi 12). Jakarta: Erlangga.

12. Kotler, P., \& Keller, K.L. (2009). Manajemen Pemasan. Jilid 2. Jakarta: Erlangga.

13. Kurniawati, D., Suharyono, \& Kusumawati, A., (2014). Pengaruh Citra Merek dan Kualitas Produk Terhadap Kepuasan dan Loyalitas Pelanggan (Studi pada Pelanggan KFC Cabang Kawi Malang). Jurnal Administrasi Bisnis, 14(2).

14. Lahap, J., Ramli, N. S., Said, N. M., Radzi, S. M., \& Zain, R. A. (2016). A study of brand image towards customer's satisfaction in the Malaysian hotel industry. Procedia-Social and Behavioral Sciences, 224, 149-157.

15. Lovelock, C., \& Wright, L. K., 2007. Manajemen Pemasaran Jasa. Indonesia: PT. Indeks.

16. Parasuraman, A. (1988). Servqual : A Multiple-Item Scale for Measuring Consumer Perception of Service Quality. Journal of Retailing, Volume 64, 12-40.

17. Pitchayadejanant, K., \& Nakpathom, P. (2016). The effect of demographic information as moderator toward relationship between service quality, customer satisfaction, and customer loyalty in Thai Low cost carriers' passengers. Journal of Marketing Management, 4(1), 172-182. 
18. Rimiyati, H., \& Widodo, C. (2014). Pengaruh citra merek, kualitas produk, kepuasan konsumen terhadap loyalitas konsumen merek Samsung Galaxy Series (Studi pada mahasiswa Universitas Muhammadiyah Yogyakarta). Jurnal Manajemen Bisnis, 5(2), 223-234.

19. Siddiqi, K.O. (2011). Between Service Quality Attributes, Customer Satisfaction and Customer Loyalty in The Retail Banking Sector in Bangladesh. International Journal of Business.

20. Sondakh, C. (2015). Kualitas Layanan, Citra Merek Dan Pengaruhnya Terhadap Kepuasan Nasabah Dan Loyalitas Nasabah Tabungan (Studi Pada Nasabah Taplus BNI Cabang Manado). Jurnal Riset Bisnis dan Manajemen, 3(1).

21. Sugiyono., 2012. Metode Penelitian Kuantitatif Kualitatif dan R\&B. Bandung: Alfabeta.

22. Zeithaml, L. (1988, July). Consumer Perceptions of Price, Quality, and Value: A Means End Model and Synthesis of Evidence. Journal of Marketing, Vol 52, 2-22.

23. Parasuraman, A., Zeithaml, V. A., \& Berry, L. L. (1988). Servqual: A multiple-item scale for measuring consumer perc. Journal of retailing, 64(1), 12.

24. Undang-Undang Republik Indonesia Nomor 21 Tahun 2008 Tentang Perbankan Syariah). 